\title{
Idiopathic pulmonary fibrosis: can cell mediated immunity markers predict clinical outcome?
}

R Meliconi, E Lalli, R M Borzi, C Sturani, V Galavotti, G Gunella, R Miniero, A Facchini, G Gasbarrini

\begin{abstract}
Most of the cells found in lung parenchyma in patients with idiopathic pulmonary fibrosis are activated $T$ lymphocytes and macrophages. The serum levels of three markers of cell mediated immunity were measured in 20 patients with idiopathic pulmonary fibrosis, in 20 normal subjects and in 12 patients with sarcoidosis to evaluate their clinical and prognostic significance in idiopathic pulmonary fibrosis. The three markers were: soluble CD8 (from activated suppressor-cytotoxic lymphocytes), soluble interleukin (IL)-2 receptors (from activated $T$ cells and macrophages), and neopterin (from activated macrophages). Patients with idiopathic pulmonary fibrosis had higher levels of all three markers than the control subjects. Soluble IL-2 receptor and neopterin tended to be lower (though not significantly) in patients with idiopathic pulmonary fibrosis than in those with sarcoidosis, whereas soluble CD8 was similar in the two groups of patients. No correlation was found between soluble IL-2 receptors or soluble CD8 and the clinical, radiological, and physiological measures of disease activity or with clinical outcome (after a mean follow up of 23 months). Tumour necrosis factor levels were also determined. Only $30 \%$ of patients with idiopathic pulmonary fibrosis or sarcoidosis had detectable circulating tumour necrosis factor; these patients had a lower percentage of bronchoalveolar lavage fluid neutrophils in their lavage fluid. Tumour necrosis factor levels did not correlate with clinical measures of severity or outcome. Thus our data support the hypothesis that cell mediated alveolitis occurs in idiopathic pulmonary fibrosis. They do not, however, provide evidence to support the use of these markers of cell mediated immunity to monitor the clinical course in these patients.
\end{abstract}

Idiopathic pulmonary fibrosis or cryptogenic fibrosing alveolitis is a chronic inflammatory disease that affects the interalveolar walls and small airways of the lungs, eventually leading to severe fibrosis and respiratory insufficiency. ${ }^{1}$ The interstitial tissue damage is associated with infiltration by macrophages and lymphocytes, both of which are found in the alveolar spaces in addition to type II alveolar cells and neutrophils. Extensive fibroblastic proliferation and moderate collagen deposition may also be found. ${ }^{1}$

An immune mediated pathogenesis has been proposed because circulating immune complexes and antinuclear antibodies are frequently detected. ${ }^{2-5}$ Other investigators have suggested the occurrence of a $T$ cell alveolitis, given the predominance in the lung of $T$ cells showing the suppressor-cytotoxic phenotype (CD8) and expressing activation markers (HLA-DR, CD25). ${ }^{67}$

Recently Tomkinson and coworkers showed that changes in the levels of the soluble form of $\mathrm{CD} 8$ (a cell free $5 \mathrm{kD}$ molecule) closely parallel the timing and magnitude of $\mathrm{CD}^{+} \mathrm{T}$ cell activation after stimulation, both in animal models and in human disease. ${ }^{8}$ Patients with chronic autoimmune inflammatory disease and those receiving exogenous antigenic stimulation often have high serum levels of soluble (s) IL-2 receptor (IL-2R, a cell free $45 \mathrm{kD}$ molecule). ${ }^{9-13}$ Finally, neopterin, a metabolite of guanosine triphosphate produced and released by monocyte-macrophages stimulated by $\gamma$ interferon, has been proposed as a reliable marker of cell mediated immunity. ${ }^{14}$

To assess the clinical and prognostic significance of these serological markers of cell mediated immunity, we have assessed the levels of soluble IL-2 receptor and CD8 and of neopterin in a group of patients with fibrosing alveolitis. We also tested the serum for the presence of tumour necrosis factor, as this cytokine, which is released by macrophages and $T$ cells, stimulates neutrophil activation and behaves as a growth factor for fibroblasts, in addition to stimulating collagenase and prostaglandin E2 production by these cells. ${ }^{15}$

\section{Methods}

PATIENTS

We obtained serum from 20 patients (nine female) with idiopathic pulmonary fibrosis, with a mean age of 58 (range 29-75) years, 11 of whom were having immunosuppressive treatment. Serum was also obtained from 12 patients with sarcoidosis (seven female) with a mean age of 44 (range 33-55) years, seven of whom were having immunosuppressive treatment. Control serum was obtained from 20 healthy age and sex matched subjects (blood donors and normal elderly subjects selected according to the Senieur protocol). ${ }^{16}$

The diagnosis of idiopathic pulmonary fibrosis was made from clinical, radiological, physiological, and histological findings. ${ }^{1}$ The 
Clinical, radiological, scintigraphic, physiological, and pathological data from patients with idiopathic pulmonary fibrosis

\begin{tabular}{|c|c|c|c|c|c|c|c|c|c|c|c|c|c|c|c|c|c|}
\hline \multirow[b]{3}{*}{ Sex } & \multirow{3}{*}{$\begin{array}{l}\text { Age } \\
(y)\end{array}$} & \multirow{3}{*}{$\begin{array}{l}\text { Disease } \\
\text { duration } \\
\text { (months) }\end{array}$} & \multicolumn{5}{|l|}{ Score } & & & & \multirow{3}{*}{$\begin{array}{l}F V C \\
\% \text { opred }\end{array}$} & \multirow[b]{3}{*}{$T L C O$} & \multicolumn{5}{|c|}{ Lavage fluid } \\
\hline & & & \multirow{2}{*}{$\begin{array}{l}\text { Dys- } \\
\text { pnoea } \\
(0-20)\end{array}$} & \multirow{2}{*}{$\begin{array}{l}\text { Radio- } \\
\text { graph } \\
(0-10)\end{array}$} & \multirow{2}{*}{$\begin{array}{l}\text { Physio- } \\
\text { logical } \\
(0-70)\end{array}$} & \multirow{2}{*}{$\begin{array}{l}C R P \\
(0-100)\end{array}$} & \multirow{2}{*}{$\begin{array}{l}\text { Gallium } \\
\text { scan } \\
(0-3)\end{array}$} & \multicolumn{3}{|c|}{ Lung biopsy } & & & \multirow{2}{*}{$\begin{array}{l}\text { Total } \\
\text { cells } \\
\left(\times 10^{3}\right)\end{array}$} & \multirow{2}{*}{$\begin{array}{l}M \\
(\%)\end{array}$} & \multirow{2}{*}{$\begin{array}{l}L \\
(\%)\end{array}$} & \multirow{2}{*}{$\begin{array}{l}N \\
(\%)\end{array}$} & \multirow{2}{*}{$\begin{array}{l}E \\
(\%)\end{array}$} \\
\hline & & & & & & & & $a$ & $b$ & $c$ & & & & & & & \\
\hline $\mathbf{M}$ & 54 & 28 & 4 & $6 \cdot 6$ & 13 & $23 \cdot 6$ & 1 & 4 & 9 & 13 & 80 & 50 & 250 & 80 & 8 & 10 & 2 \\
\hline F & 64 & 50 & 10 & 7 & 42 & 59 & 1 & 2 & 11 & 13 & 68 & 41 & & & ND & & \\
\hline $\mathbf{F}$ & 75 & 72 & 20 & 8 & 55 & 83 & 0 & 2 & 16 & 18 & 53 & 38 & & & ND & & \\
\hline $\mathbf{M}$ & 65 & 48 & 18 & 8 & 52 & 78 & 0 & 2 & 16 & 18 & 51 & 42 & 320 & 74 & 5 & 16 & 5 \\
\hline$F$ & 66 & 48 & 12 & 6 & 52 & 70 & 3 & 4 & 10 & 14 & 45 & 48 & 310 & 76 & 4 & 16 & 4 \\
\hline $\mathbf{M}$ & 71 & 51 & 18 & $6 \cdot 6$ & 46 & $70 \cdot 6$ & 0 & 2 & 17 & 19 & 59 & 51 & 250 & 82 & 6 & 10 & 2 \\
\hline $\mathbf{M}$ & 58 & 24 & 8 & $4 \cdot 6$ & 14 & $26 \cdot 6$ & 2 & 10 & 2 & 12 & 76 & 75 & 370 & 79 & 11 & 10 & 0 \\
\hline $\mathbf{M}$ & 62 & 70 & 18 & 6.6 & 50 & $74 \cdot 6$ & 0 & 2 & 15 & 17 & 52 & 54 & 315 & 75 & 9 & 14 & 2 \\
\hline $\mathbf{M}$ & 30 & 60 & 14 & $5 \cdot 6$ & 38 & $57 \cdot 6$ & 1 & 6 & 10 & 16 & 61 & 60 & & & ND & & \\
\hline $\mathrm{M}$ & 68 & 18 & 12 & $7 \cdot 3$ & 40 & $59 \cdot 3$ & 0 & 8 & 14 & 18 & 57 & 56 & 520 & 76 & 10 & 14 & 0 \\
\hline F & 46 & 52 & 14 & 3 & 30 & 47 & 1 & 6 & 11 & 17 & 67 & 58 & 320 & 75 & 6 & 19 & 0 \\
\hline F & 40 & 60 & 18 & 8 & 48 & 74 & 1 & 2 & 18 & 20 & 33 & 38 & & & ND & & \\
\hline F & 53 & 48 & 18 & 8 & 42 & 68 & 1 & 5 & 16 & 21 & 45 & 36 & & & ND & & \\
\hline F & 73 & 30 & 16 & 6 & 25 & 47 & 2 & 4 & 12 & 16 & 69 & 41 & & & ND & & \\
\hline $\mathbf{M}$ & 53 & 30 & 16 & $4 \cdot 3$ & 47 & $67 \cdot 3$ & 1 & 6 & 11 & 17 & 39 & 45 & 320 & 79 & 8 & 7 & 6 \\
\hline$M$ & 71 & 72 & 14 & $7 \cdot 3$ & 51 & $72 \cdot 3$ & 2 & 4 & 12 & 16 & 64 & 40 & 290 & 81 & 6 & 9 & 4 \\
\hline $\mathbf{F}$ & 29 & 75 & 12 & 8 & 55 & 75 & 0 & 4 & 17 & 21 & 28 & 33 & 210 & 78 & 7 & 11 & 4 \\
\hline $\mathbf{M}$ & 62 & 29 & 6 & 6 & 19 & 31 & 2 & 2 & 9 & 11 & 65 & 59 & 350 & 65 & 2 & 27 & 5 \\
\hline$M$ & 75 & 36 & 14 & $5 \cdot 6$ & 14 & 33.6 & 1 & 2 & 4 & 6 & 85 & 65 & 290 & 77 & 6 & 15 & 2 \\
\hline $\mathbf{M}$ & 43 & 12 & 6 & 4 & 9 & 19 & 1 & 16 & 10 & 26 & 75 & 89 & 330 & 82 & 16 & 2 & 0 \\
\hline
\end{tabular}

CRP-clinical, radiological, pathological score (see under “Methods"); a-cellular infiltration score (0-21); b-fibrosis score (0-24); c-total score (0-45); FVC—forced vital capacity; TLCo-carbon monoxide transfer factor; $M-$ macrophages; $L$ - lymphocytes; $N$-neutrophils; $E-$ eosinophils; ND-not determined.

diagnosis of sarcoidosis was confirmed histologically. ${ }^{17}$ All patients with idiopathic pulmonary fibrosis or sarcoidosis had a transbronchial or open lung biopsy. No associated well defined connective tissue disease was present in the patients with idiopathic pulmonary fibrosis ("lone" idiopathic pulmonary fibrosis). There was no history of occupational exposure or of sensitivity to drugs or organic dust. Clinical, radiological, scintigraphic, physiological, and pathological data from the patients with idiopathic pulmonary fibrosis are shown in the table.

Gallium-67 scans were scored as described by Nosal et $a l^{8}$ and the histological appearances of lung tissue according to the system of Watters et al. ${ }^{19}$ The single breath transfer factor for carbon monoxide ( $\mathrm{TLCO}_{\mathrm{L}}$ ) corrected for alveolar ventilation ( $\mathrm{TLCO}_{\mathrm{L}} / \mathrm{VA}$ ) was measured as described, ${ }^{20}$ and results are given as $\%$ predicted. Clinical impairment was also calculated serially from a clinical-radiographicphysiological score (CRP), as proposed by Watters et al. ${ }^{19}$ The score is derived from seven variables, each weighted according to an estimate of its relative importance derived from published reports. The components and the corresponding percentages of the score are:

1 historically derived activity required to cause dyspnoea $(20 \%)$

2 chest radiograph $(10 \%)$

3 forced vital capacity $(10 \%)$

4 forced expiratory volume in one second $\left(5^{\circ}{ }_{0}\right)$

5 thoracic gas volume or functional residual capacity $(10 \%)$

6 transfer factor for carbon monoxide $(5 \%)$

7 the resting arteriovenous oxygen gradient $\left(\mathrm{A}-\mathrm{aPo}_{2}\right)\left(10_{0}^{\circ}\right)$

8 exercise induced reduction in oxygen saturation indexed to the fraction of predicted maximal oxygen consumption achieved during exercise $(30 \%)$.
The score rises as impairment increases; the maximum score is 100 .

After a mean 23 (SEM 3.9) months all patients were reassessed clinically; 12 had deteriorated (nine died), six were stable, and two had improved. Clinical assessment of improvement or deterioration was made according to whether one or more of the following changes had occurred: a change in dyspnoea score of more than 6 , a change in FVC ${ }^{\circ}$ predicted of more than 8 , a change in CRP score of more than 10.

Bronchoalveolar lavage specimens were obtained from 14 patients with idiopathic pulmonary fibrosis by lavaging the right middle lobe through a flexible fibreoptic bronchoscope with $60 \mathrm{ml}$ aliquots of normal saline buffered to $\mathrm{pH} 7.0$ with $8.4 \%$ sodium bicarbonate. $^{21}$ The mean (SD) volume of fluid introduced was 360 (66) $\mathrm{ml}$ and of fluid retrieved was 124 (36) $\mathrm{ml}$. A centrifuged specimen stained with Wright-Giemsa was used to obtain a differential cell count (table).

ASSAYS OF SOLUBLE CD8 AND IL-2R AND OF TUMOUR NECROSIS FACTOR

Serum concentrations of sCD8 and sIL-2R and of tumour necrosis factor were assessed with commercially available enzyme linked immunoassays ( $T$ Cell Sciences, Cambridge, Massachusetts), which use two monoclonal antibodies directed against different epitopes of the molecule. ${ }^{82-25}$ The tests were performed according to the manufacturer's instructions. All serum samples were tested in duplicate. Absorbance values from patients' samples were plotted on a standard curve obtained from reference samples. The standard curves contained $0,100,400,1000$, and 2000 units of soluble CD8; $0,400,800$, and 1600 units/ml of sIL-2R; and $0,40,150,500$ and $1000 \mathrm{pg} / \mathrm{ml}$ of recombinant human tumour necrosis factor. The detection limit of the assays was $10 \mathrm{pg} / \mathrm{ml}$. rTNF ( $1 \mathrm{mg}$ ) used as 


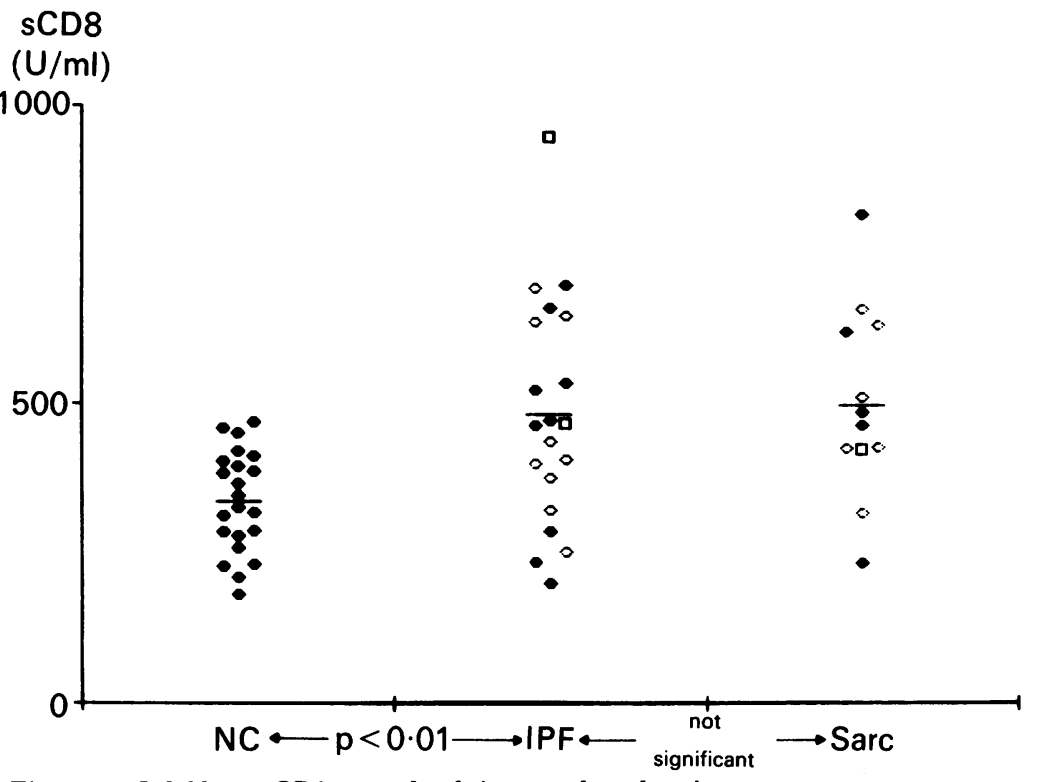

Figure 1 Soluble (s) CD8 serum levels in controls and patients.

$\square$ Untreated; $\bigcirc$ corticosteroid treated; $\square$ not corticosteroid treated; $N C$-normal controls; IPF-patients with idiopathic pulmonary fibrosis; Sarc-patients with sarcoidosis.

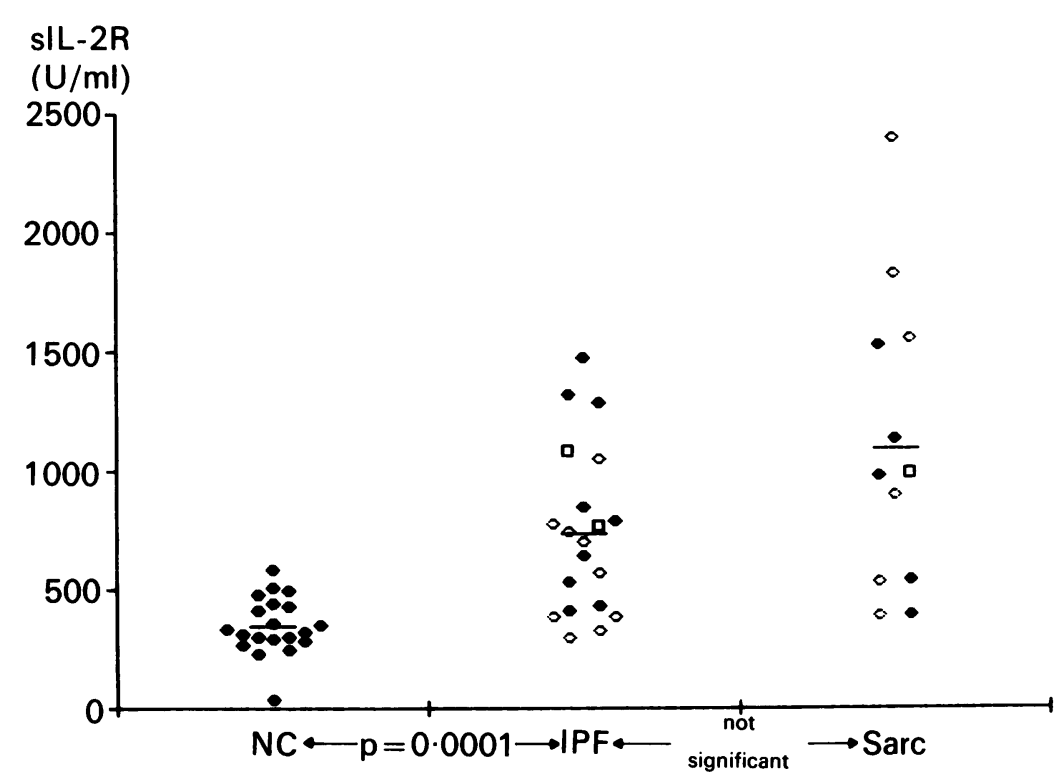

Figure 2 Interleukin (IL)-2R serum levels in controls and patients. Symbols and abbreviations as in figure 1.

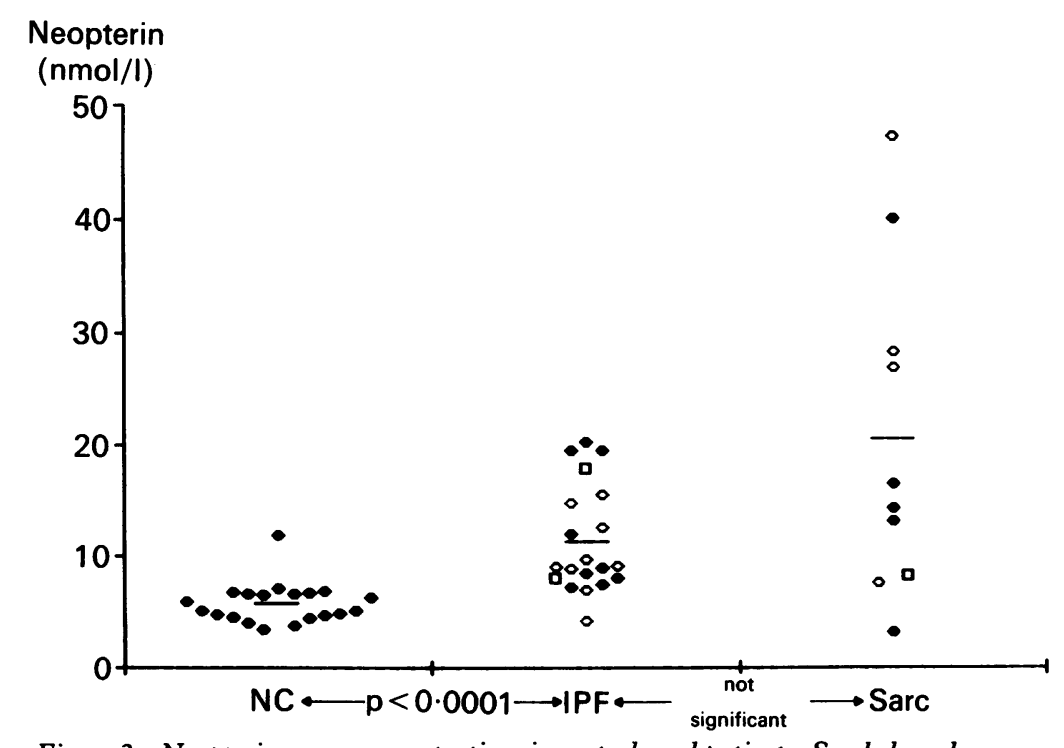

Figure 3 Neopterin serum concentrations in controls and patients. Symbols and abbreviations as in figure 1. a standard for this assay is equivalent to $2 \times$ $10^{7}$ units of activity as defined by the L929 cytotoxicity test. ${ }^{25}$ The optical density units were converted into the appropriate units for each substance by using the BIO RAD ELISA data analysis software.

Neopterin concentrations were measured with a commercial radioimmunoassay kit (Neopterin-RIAcid, Henning, Berlin, West Germany). ${ }^{26}$

\section{STATISTICAL ANALYSIS}

The Mann-Whitney U test was used to compare the concentrations of mediators in serum from patients with idiopathic pulmonary fibrosis and the control groups. The Kendall coefficient of correlation (tau, $\tau$ ) was used to measure the correlation between IL-2R, tumour necrosis factor, and neopterin, and the correlation between the three mediators and the clinical, radiological, physiological, cytological, and follow up findings in the patients with idiopathic pulmonary fibrosis.

\section{Results}

The concentrations of sCD8, sIL-2R, and neopterin were significantly greater in patients with idiopathic pulmonary fibrosis than in the control subjects (figs 1-3). Patients with sarcoidosis had higher concentrations of sIL-2R and neopterin than did those with idiopathic pulmonary fibrosis, though the differences were not significant; sCD8 was similar in the two groups. The patients with idiopathic pulmonary fibrosis who was receiving corticosteroids had lower concentrations of sIL-2R (mean 574 (SD 253.2) $\mathrm{U} / \mathrm{ml}$ ) than the untreated patients $(850(401) \mathrm{U} / \mathrm{ml} ; \mathrm{p}<0.05)$. sCD8 and neopterin concentrations did not differ in the patients who were and were not receiving corticosteroids. Detectable levels of tumour necrosis factor were present in seven of 20 patients with idiopathic pulmonary fibrosis and in four of 12 patients with sarcoidosis (fig 4).

SCD8 and sIL-2R concentrations did not correlate with the clinical, radiological, and physiological data (shown in the table).

Neopterin concentrations correlated negatively with pathological scores and positively with FVC \% predicted. Patients with detectable circulating tumour necrosis factor had a lower percentage of neutrophils in lavage fluid (those with tumour necrosis factor: mean 8.8\% (SD 5.1\%) neutrophils; those without: $15.1 \%(5.3 \%) ; \mathrm{p}<0.05)$. There was a linear correlation $(\tau=0.32, p<0.05)$ between sIL-2R and neopterin concentrations in the patients with idiopathic pulmonary fibrosis. There was no correlation between sCD8, sIL$2 R$, neopterin, or tumour necrosis factor and the clinical outcome at the end of the follow up period.

\section{Discussion}

Activated T lymphocytes have recently been found in lung biopsy specimens from patients with idiopathic pulmonary fibrosis. ${ }^{6} \mathrm{~T}$ cells 


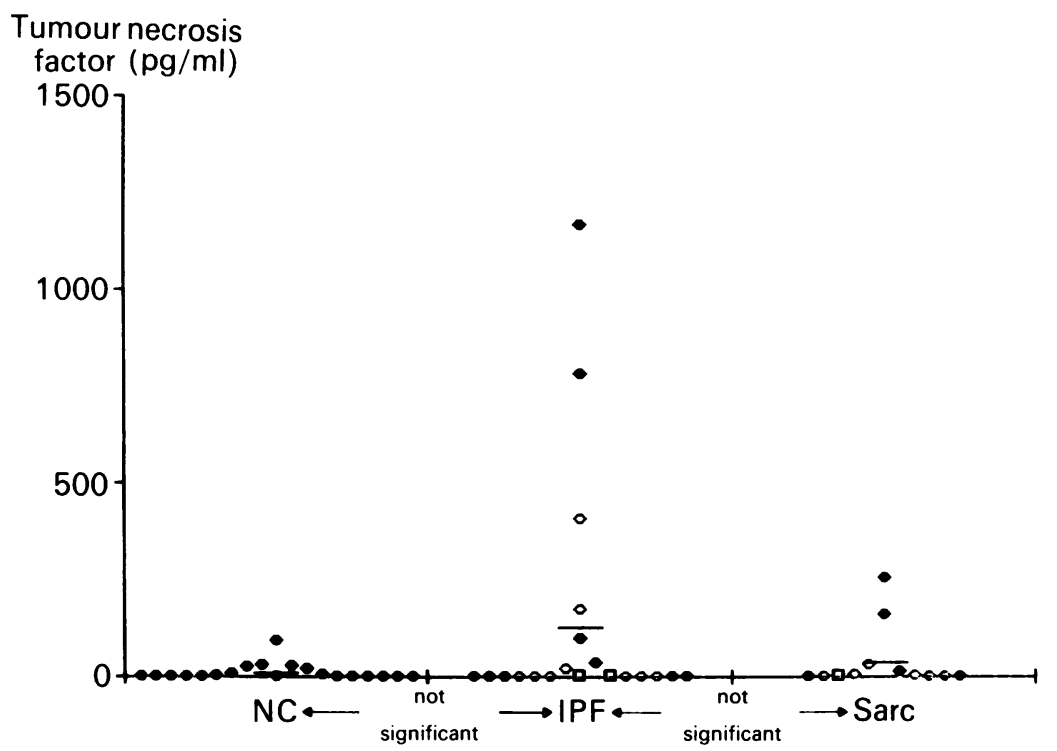

Figure 4 Tumour necrosis factor (TNF) serum levels in controls and patients. Symbols and abbreviations as in figure 1 .

with the suppressor-cytotoxic phenotype $\left(\mathrm{CD8}^{+}\right)$constituted the great majority of the cells in alveolar septa and in the mucosa of small inflamed airways. ${ }^{6}$

$\mathrm{CD8}^{+} \mathrm{T}$ cell activation is associated with a parallel release of CD8 protein, which can be measured in the serum of patients. ${ }^{27}$ Our patients with idiopathic pulmonary fibrosis had increased concentrations of serum sCD8, which probably reflected the presence of activated suppressor-cytotoxic cells in the lung parenchyma.

Other markers of cell mediated immunity, sIL-2R and neopterin, are also increased in the sera of patients with idiopathic pulmonary fibrosis. The positive correlation between concentrations of sIL-2R and neopterin could reflect primary activation of monocytesmacrophages because expression of IL-2R has been found on normal and malignant monocytes, ${ }^{28}$ and neopterin is a guanosine triphosphate metabolite synthesised by $\gamma$ interferon activated macrophages. ${ }^{29}$ Serum concentrations of sIL-2R and neopterin tended to be higher in patients with sarcoidosis than those in patients with idiopathic pulmonary fibrosis, as has been shown previously. ${ }^{11}$

The fact that $\mathrm{SCD} 8$ concentrations were similar in the two interstitial lung diseases is interesting; it suggests that there is a higher percentage of activated $\mathrm{CD}^{+}$cells in patients with idiopathic pulmonary fibrosis than in those with sarcoidosis.

The lack of correlation between $\mathrm{SCD8}$ or sIL-2R concentrations and the clinical, pathological, and physiological measures or the clinical outcome in the patients with idiopathic pulmonary fibrosis may be because the circulating concentrations of these markers does not mirror local inflammatory reactions completely. In sarcoidosis, where a trend towards higher concentrations of IL-2R was found, Lawrence and coworkers ${ }^{11}$ found only a weak association between IL-2R levels and gallium-67 lung scans among the various measures of disease activity that they evalu- ated. Alternatively, the lack of any correlation may be explained by a closer association of clinical severity with the degree of fibrosis than with inflammation. It is noteworthy that many of our patients had disease of relatively long duration. The finding that neopterin concentrations correlated positively with FVC ${ }_{0}$ predicted values and inversely with total pathological scores supports this hypothesis; immune mediated inflammatory processes may burn out in the late (fibrotic) stage of the disease.

Activated $T$ cells and macrophages synthesise and release a number of cytokines whose main function is immunoregulation. The biological activities ${ }^{150}$ of tumour necrosis factor would be compatible with a role in idiopathic pulmonary fibrosis. The finding of detectable amounts of tumour necrosis factor in serum in only a third of the patients with idiopathic pulmonary fibrosis may support a pathogenetic role for this cytokine in a few patients, particularly those with non-neutrophilic alveolitis. The association of tumour necrosis factor in the serum with a low percentage of neutrophils in lavage fluid is consistent with the recent finding that tumour necrosis factor promotes adherence of neutrophils and inhibition of chemotactic migration. ${ }^{31}$ In the patients with high concentrations of tumour necrosis factor neutrophils may be more inclined to adhere to the interstitium of the alveolar wall rather than migrate into the alveolar spaces.

In conclusion, the results of our study support the hypothesis that cell mediated immune phenomena occur in idiopathic pulmonary fibrosis, but none of the markers we studied provided a useful measure of clinical activity.

We thank Mrs Anne Collins for revising the English manuscript and Mrs Patrizia Rappini for typing assistance.

1 King TE. Idiopathic pulmonary fibrosis. In: Schwarz MI, King TE, eds. Interstitial lung disease. Toronto: Decker, 1988:139-69.

2 Dreisin RB, Schwarz MI, Thophilopoulos AN, Stanford RE. Circulating immune complexes in idiopathic interRE. Circulating immune complexes in idiopathic
stitial pneumonias. N Engl J Med 1978;298:353-7.

3 Haslam P, Thompson B, Mohammed I, et al. Circulating immune complexes in patients with cryptogenic fibrosing immune complexes in patients with cryptogen
alveolitis. Clin Exp Immunol 1979;37:381-90.

4 Holgate ST, Haslam P, Turner Warwick M. The significance of antinuclear and DNA antibodies in cryptogenic fibrosing alveolitis. Thorax 1983;78:67-70.

5 Chapman JR, Charles PJ, Venables PJW, et al. Definition and clinical relevance of antibodies to nuclear ribonucleoprotein and other nuclear antigens in patients with cryptogenic fibrosing alveolitis. Am Rev Respir Dis 1984; 130:439-43.

6 Kradin RL, Divertie MB, Colvin RB, et al. Usual interstitial pneumonitis is a T-cell alveolitis. Clin Immunol Immunopathol 1986;40:224-35.

7 Kallemberg CGM, Schilizzi BM, Beaumont F, Poppema S, De Leij L, The TH. Expression of class II MHC antigens on alveolar epithelium in fibrosing alveolitis. Clin Exp Immunol 1987;67:182-90.

8 Tomkinson BE, Brown MC, Ip SH, Carrabis S, Sullivan JL. Soluble CD8 during T cell activation. J Immunol 1989; 142:2230-6.

9 Balderas RS, Josimovic-Alasevic O, Diamanstein T, Dixon FJ, Theophilopoulos AN. Elevated titers of cell-free interleukin 2 receptor in serum of lupus mice. $J$ Immunol 1988;139:1496-500.

10 Wolf RE, Brelsford WG. Soluble interleukin-2 receptors in systemic lupus erythematosus. Arthr Rheum 1988;31: $729-35$.

1 Lawrence EC, Brousseau KP, Berger MB, Kurman CC Marcon L, Nelson DL. Elevated concentrations of soluble interleukin-2 receptors in serum samples and bronchoalveolar lavage fluids in active sarcoidosis. Am Rev Respir Dis 1988;137:759-64. 
12 Josimovic-Alasevic $\mathrm{O}$, Feldmeir $\mathrm{H}$, Zwingenberger $\mathrm{K}$, et al. Interleukin 2 receptor in patients with localized and systemic parasitic diseases. Clin Exp Immunol 1988; 72:249-54.

13 Pizzolo G. The soluble interleukin 2 receptor as a new biological marker in diseases. Immunol Clin 1988;7:13-21.

14 Fuchs D, Hausen A, Reibnegger G, Werner ER, Dietrich MP, Watcher $H$. Neopterin as a marker for activated cellmediated immunity: application in HIV infection. mediated immunity: applicatio

15 Beutler G, Cerami A. Cachectin: more than a tumor necrosis factor. $N$ Engl J Med 1987;316:379-85.

16 Ligthart G, Coprberand JX, Fournier C, et al. Admission criteria for immunogerontological studies in man: the SENIEUR protocol. Mech Ageing Dev 1984;28:47-55.

17 Mitchell DN, Scadding JG, Heard BE, Hinson KFW. Sarcoidosis: histopathological definition and clinical diagnosis. J Clin Pathol 1977;30:395-408.

18 Nosal A, Schleissner LA, Mishkin FA, Lieberman J. Angiotensin I-converting enzyme and Gallium scan in noninvasive evaluation of sarcoidosis. Ann Intern Med 1979;90:328-34.

19 Watters LC, King TE, Schwarz MI, Waldron JA, Stanford RE Cherniack RM A clinical, radiologic and physiologic scoring system for the scoring system for the longitudinal assessment of patients with idiopathic p

20 Olgivie CM, Forster RE, Blakemoie WS, et al. A standard breath technique for the clinical measurement of the capacity of the lung for carbon monoxide. J Clin Invest 1957;36:1-9.

21 Hunninghake GW, Gadek JE, Kawanami OK, Ferrans VJ, Crystal RG. Inflammatory and immune processes in the lung in health and disease: evaluation by bronchoalveolar lavage. Am J Pathol 1979;97:148-206.

22 Rubin LA, Kurman CC, Fritz ME, et al. Soluble interleukin-2 receptors are released from activated human lymphoid cells in vitro. $J$ Immunol 1985;135:3172-7.
23 Rubin LA, Kurman CC, Biddison WE, Goldman ND, Nelson DL. A monoclonal antibody, 7G7/B6, binds to an epitope on the human interleukin-2 receptor that is distinct from that recognized by $\mathrm{IL}-2$ or anti-Tac. Hybridoma 1985;4:91-102.

24 Cuturi MC, Murphy M, Costa-Giomi MP, et al. Independent regulation of tumor necrosis factor and lymphotoxin production by human peripheral blood lymphocytes. Exp Med 1987;165:1581-94.

25 Flick DA, Glifford GE. Comparison of in vitro cell cytotoxic assays for tumor necrosis factor. J Immunol Methods 1984;68:167-75.

26 Rokos H, Rokos K, Kern P, Dietrich M. Radioimmunoassay for neopterin in serum. Levels in patients with viral infections, lymphoadenopathy syndrome, AIDS, leprosy and normals after hepatitis vaccination. In: Pfleiderer $W$ Wachter $\mathrm{H}$, Curtius $\mathrm{H} \mathrm{Ch}$, eds. Biochemical and clinical aspects of pteridins. Berlin: de Gruyter, 1984:503-13.

27 Fujimoto J, Levy S, Levy R. Spontaneous release of the Leu 2a (T8) molecule from human T cells. J Exp Med 1983; 159:752-66.

28 Herrmann F, Cannistra SA, Levine H, Griffin JD. Expression of interleukin 2 receptors and binding of interleukin 2 by gamma-interferon induced leukemic and normal monocytic cells. J Exp Med 1985;162:1111-6.

29 Huber C, Batchlor JR, Fuchs D, et al. Immune responseassociated production of neopterin. Release from macrophages primarily under control of interferon-gamma. $J$ phages primarily under cont
Exp Med 1984;160:310-6.

30 Piguet PF, Grau GE, Collart M, Vassalli P, Kapanci Y. GVHR induces an alveolitis involving TNF alpha. Bone Marrow Transplant 1988;3:111.

31 Kownatzki E, Kapp A, Uhrich S. Modulation of human neutrophilic granulocyte functions by recombinan human tumor necrosis factor and re lymphotoxin. Promotion of adherence, inhibition of chemotactic migration and superoxide anion release from adherent cells. Clin Exp Immunol 1988;74:143-8. 